\title{
Local Government Policy Evaluation Assessment in Domestic Waste Management (Case Study Approach to Evaluation of Road Sweep Service Performance in Kediri, Indonesia)
}

\author{
Yenik Pujowati \\ Departement of Social and Political Sciences \\ University of Wijaya Kusuma Surabaya \\ yenikpujo@uwks.ac.id
}

\begin{abstract}
This study aims to determine government policies in domestic waste management carried out in the city of Kediri and evaluate the implementation of performance policies for domestic waste management in the city of Kediri. Based on law No.18 of 2008 concerning waste management, and the policy of regional regulation No. 3 of 2015 concerning waste management in the city of Kediri. Based on these regulations, it is very important to strengthen the performance of the service officers in the road sweep in the city of Kediri. The research method used is qualitative. Data is obtained through observation and analysis of secondary data, as well as primary data. The results of this study indicate that under the service performance indicators of street sweepers in Kediri City are still not efficient and road sweeping technical work is still not productive. The results of the study can be concluded based on local government policies in improving the performance of road sweeping services in the City of Kediri so that the performance of road sweeping officers is more optimal, then the Government of Kediri City is recommended to make standard operating procedures (SOP) for road sweeping officers in Kediri City.
\end{abstract}

Keywords: policy, domestic waste, performance of road sweep officer services.

\section{INTRODUCTION}

Municipal waste is defined as garbage dumped by the city community. The problem of municipal garbage is the volume of large garbage and exceeding the capacity of landfills (Sudradjat, 2007).Garbage impacts health, the environment, and socio-economic (Basriyanta, 2011). The issue of waste can hamper the development of regional autonomy and reduce the flow of investors (Sucipto, 2012).

Waste management is a response to the actual generation of waste, including its collection, transportation, recovery, disposal, including control of these processes, and assessment of the impact of the waste disposed of (Pongracz et al., 2004; Skorupskaite and Junevičius, 2017). Waste management in Kediri still relies on the government's role. The janitor took the garbage from the residents and brought the garbage to the polling station to be transported to the landfill by the sanitation department. The percentage of people served in kediri is still very high, meaning that the participation of the community is still low. In Kediri, community empowerment began in managing waste to deal with waste. The city of Surabaya produces 2,177 tons of garbage per day, which enters landfill 1,480 tons per day. The Surabaya Regional Government involves the government, the private sector, and the community in managing waste (Sarbidi, 2009). In the city of Bandung, the responsibility for waste management is divided into two, namely transportation from home to polling stations is the responsibility of the community while from TPS to TPA is the responsibility of the government (Muttaqien, 2014).

Kediri city is one adipura city in 2009 , but the town of Kediri still faces problems of waste management. In 2009 the waste problem in the city of Kediri increased so that it was unable to accommodate piles of garbage. Management in Kediri has not been well characterized by a large amount of un-transported waste from TPS and that has accumulated 
in several parts of the city. The implementation of bureaucratic public services is required to provide good service for the community. Services carried out by the government can be called Good Governance. One area of public services provided by the government is the performance of waste management services. Law No. 18 of 2008 concerning Waste Management becomes a legal umbrella in managing cleanliness. Regional Regulation No. 3 of 2015 concerning the Management of waste in the city of Kediri. These problems are a general picture that hinders the service performance of road sweeping officers in the cleanliness and gardening environment of Kediri city.

Therefore, this article aims to find out government policies in domestic waste management carried out in the city of Kediri and evaluate the implementation of domestic waste management performance policies in the city of Kediri.

\section{Methods}

This research uses a qualitative descriptive research method. Data is obtained through observation and analysis of secondary data. Data that has been collected, both primary and secondary data, then analyzed and interpreted by giving conclusions. Researchers aim to describe, analyze and explain phenomena deeply through data collection. The focus of the problem in this study was the service performance of road-sweeping officers at the Kediri City Sanitation and Landscaping Office.

\section{ReSults And Discussion}

\section{A. The local government of the City of Kediri is supported} by Infrastructure in improving the Service Performance of Road Sweeper Officers at the Kediri City Environmental and Landscaping Service Office.

Every country must provide public services to realize the welfare of the community. waste management as a certain environmental area has become the country's political agenda (Skorupskaite and Junevičius, 2017). The performance of road cleaning services is one of the main tasks and functions of the field of environmental hygiene and gardening services in the city of Kediri, so that road sweeping officers are formed for road cleanliness in the City of Kediri. Garbage originating from the highway, which comes from cleaning the road which generally consists of paper, boxes, dust, rocks, sand, torn tires, falling vehicle parts, leaves, plastic, and so on.

Before entering the 2018 budget year, in one day every officer washed the road in the morning and evening. With technical work sweeping the morning starting at $05.00 \mathrm{WIB}$ until completion of the work, while in the afternoon starting at 15.00 WIB until finished. Based on the results of monitoring and evaluation revealed that the technical work of sweeping the road is still less efficient and less productive.

Regional government through DLKHP Kediri city in improving solid waste service performance related to the technical work of the new road sweep is the sweep officer only works for 4 hours and must be in place within that period, besides the sweeping workload is added according to the measured and calculated standard based on the number of roads that were swept divided by the human resources (HR) of road sweeping officers in the City of Kediri. In general, the new idea of technical work on road sweeping is aimed at:

a. The realization of the Environment in the City of Kediri that is healthy, green, and clean;

b. Implementation of the translation of the Auth of DLHKP in Kediri City, especially in the Waste and Waste Management Sector.

c. Application and Enforcement of regional regulations of Kediri City, No. 03 of 2015 concerning waste management.

Specifically, the new technical idea of road sweeping works aims to:

a. Realization of Roads Cleanliness in the City of Kediri.

b. Equivalent Workload Over Location of Roads Cleansing.

c. Optimization of Tasks, Responsibilities, and Results of Cleaned Locations.

d. Time and Cost Efficiency, due to 1 (One) Time Shift in a day

e. Facilitate monitoring and evaluation in the execution of work.

The road sweeping service performance begins with the calculations of the total area of the road that is done manually and divided by sub-district, this is done so that it is easier and more valid in the division of workloads of road sweeps and staff personnel sweeping the road. Measurements began from the sidewalk to the ground and the asphalt that was swept by the officers from the right and left sides of the road. Here is an Example of Measurement in the Pesantren District:

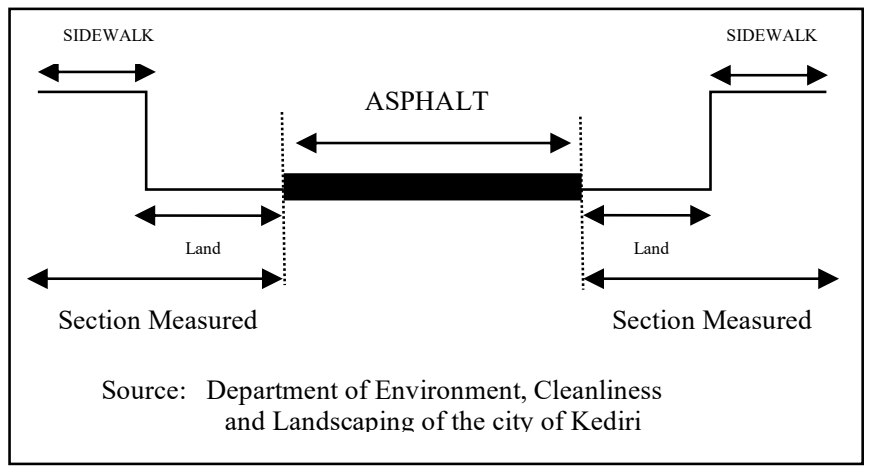




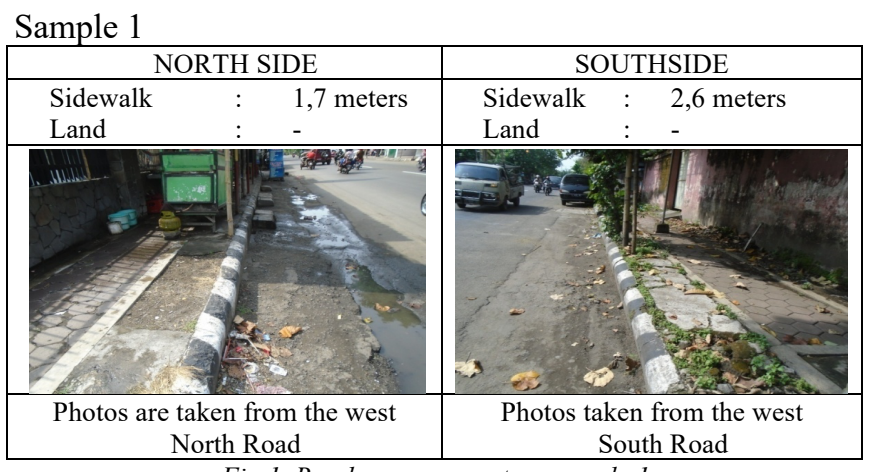

Fig 1. Road measurement on sample 1

Source: Department of Environment, Cleanliness, and Landscaping of the city of Kediri

\section{Sample 2}

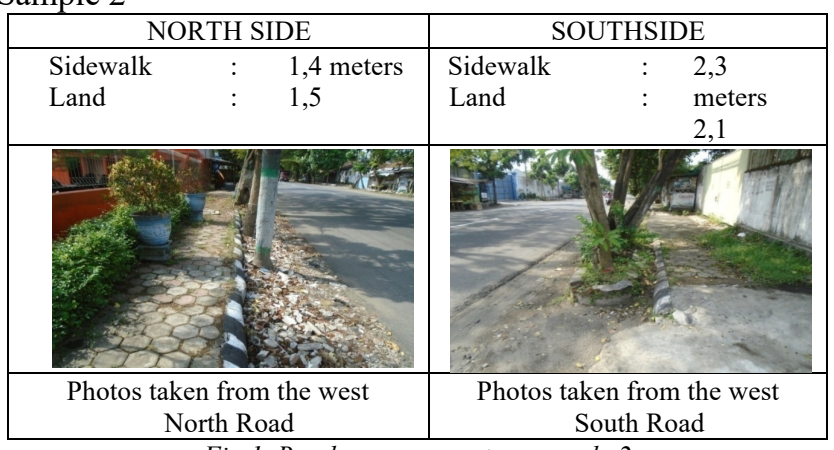

Fig 1. Road measurement on sample 2

Source: Department of Environment, Cleanliness, and Landscaping of the city of Kediri.

Sample 3

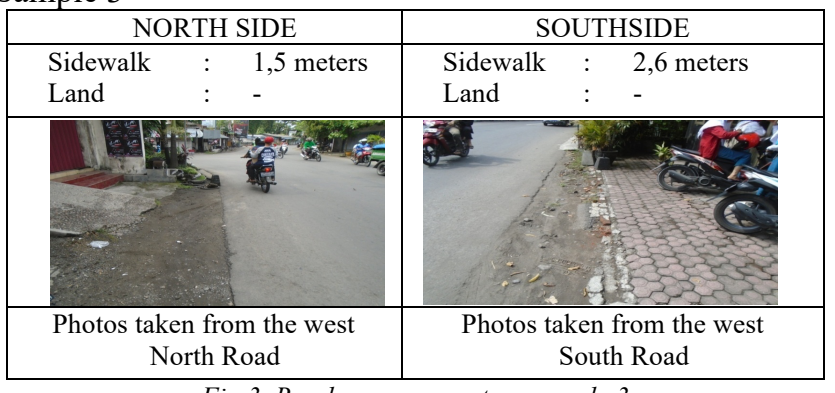

Fig 3. Road measurement on sample 3

Source: Department of Environment, Cleanliness, and Landscaping of the city of Kediri.

Based on the picture above, after taking a thorough measurement, the process of calculating the width of the road sweep is continued by recapitulating the results to make the calculation process easier (see Table 1).

Table 1.

A road sweep width measurement

\begin{tabular}{|l|c|c|c|c|}
\hline \multirow{2}{*}{ UNIT IN METERS } & \multicolumn{2}{|c|}{ NORTH SIDE } & \multicolumn{2}{c|}{ SOUTHSIDE } \\
\cline { 2 - 5 } & Sidewalk & Land & Land & Sidewalk \\
\hline Sample 1 & 1,7 & - & - & 2,6 \\
\hline Sample 2 & 1,4 & 1,5 & 2,1 & 2,3 \\
\hline Sample 3 & 1,5 & - & - & 2,6 \\
\hline Average Length & 1,53 & 0,50 & 0,70 & 2,50 \\
\hline Road Sweep Width & 5,23 & & & \\
\hline Road Length & 2366 & & & \\
\hline
\end{tabular}

Source: Department of Environment, Cleanliness, and Landscaping of the city of Kediri
Based on the above description, it explains the broad standard of road sweeping that has been measured, each officer must complete a workload of road sweeping of \pm $3,212.66 \mathrm{~m}^{2} /$ person in a day. In addition to a large workload, road sweeping officers also pose a high risk to health and safety. Street sweepers in carrying out their work are very vulnerable to various risks, especially safety and health risks such as the risk of hearing loss due to noise, stress, dehydration, being hit by a vehicle, as well as health problems due to fatigue, bacteria, respiratory system disorders caused by inhaling vehicle fumes and dust, as well as viruses (Zainulet al., 2019).

The large workload for road sweeping officers will also have an impact on delays in transporting waste in the City of Kediri. The impact of this delay will be very harmful to the surrounding environment. An improperly organized waste collection process can harm the natural environment and disrupt the lives of local people public (Lapko, et al., 2021).

The facilities used for road sweeping activities include field uniforms, broomsticks, sack, gloves, boots, carts, 3wheeled vehicles, and 120 liters of containers. Current conditions have occurred problems in the implementation of waste management, one of which is an increase in waste generation, there are several other problems, namely: infrastructure and facilities are not optimally adequate, lack of human resources, many areas of waste generation have not been touched by Environmental Service officers, People don't care enough to participate in breaking down and reusing waste (Muthmainnah and Adris, 2020).

However, Regulation No 18/2008 appears not to have been well implemented even 12 years after it was signed. Under this regulation, the Indonesian government tries to change the open dumping paradigm to reuse, reduce, and recycling (3R). Most of the local governments in Indonesia are only collecting, transporting, and then dumping the garbage to the landfill without taking into account the selection, separation, transport, and management aspects of the landfill. (Lubna Salsabila, el al.,2021).

Table 2 below presents the distribution of workloads in the Pesantren District and Table: 3describes the schedule for the shift in positions of officers sweeping the road at the Kediri City Park and Sanitation Office. 
Table 2.

Distribution of Road Sweep Workload for Pesantren District in 2018.

\begin{tabular}{|c|c|c|c|c|c|c|c|}
\hline$\overline{\text { No }}$ & $\begin{array}{l}\text { Street } \\
\text { Name }\end{array}$ & $\begin{array}{l}\text { Road } \\
\text { Area }\end{array}$ & $\begin{array}{c}\text { Sweep } \\
\text { Width } \\
\text { of } \\
\text { Road }\end{array}$ & $\begin{array}{c}\text { Length of } \\
\text { Road } \\
\text { Sweeping }= \\
\text { Road Area } \\
\text { / Road } \\
\text { Width }\end{array}$ & $\begin{array}{l}\text { Total } \\
\text { Road } \\
\text { Area }\end{array}$ & $\begin{array}{c}\text { Total } \\
\text { Road } \\
\text { Area } \\
\text { Kec. } \\
\text { Pesantren }\end{array}$ & $\begin{array}{l}\text { Work } \\
\text { load }\end{array}$ \\
\hline 1 & $\begin{array}{l}\text { Brigjend } \\
\text { Pol Imam } \\
\text { Bachri }\end{array}$ & 3093,5 & 5,23 & 591 & 3093,5 & 28384,41 & 3093,5 \\
\hline 2 & $\begin{array}{l}\text { Brigjend } \\
\text { Pol Imam } \\
\text { Bachri }\end{array}$ & 3093,5 & 5,23 & 591 & 3093,5 & & 3093,5 \\
\hline 3 & $\begin{array}{l}\text { Brigjend } \\
\text { Pol Imam } \\
\text { Bachri }\end{array}$ & 3093,5 & 5,23 & 591 & 3093,5 & & 3093,5 \\
\hline 4 & $\begin{array}{l}\text { Brigjend } \\
\text { Pol Imam } \\
\text { Bachri }\end{array}$ & 3093,5 & 5,23 & 591 & 3093,5 & & 3093,5 \\
\hline 5 & $\begin{array}{l}\text { Letjen } \\
\text { Sutoyo }\end{array}$ & 1959 & 3,25 & 603 & 3244,20 & & 3244,2 \\
\hline 6 & $\begin{array}{l}\text { Mayjend } \\
\text { Panjaitan }\end{array}$ & 1285,2 & 3,40 & 378 & & & \\
\hline 7 & Cendana & 3219 & 4,83 & 666 & 3109,21 & & 3109,21 \\
\hline 8 & Cendana & 304 & 4,83 & 63 & 3219 & & 3219 \\
\hline 9 & Suparman & 733 & 3,20 & 229 & 3219 & & 3219 \\
\hline & Suparman & 2915 & 3,20 & 911 & & & \\
\hline & $\begin{array}{l}\text { Kapt. } \\
\text { Tendean }\end{array}$ & 2486 & 6,40 & 388 & & & \\
\hline 10 & $\begin{array}{l}\text { Kapt. } \\
\text { Tendean }\end{array}$ & 3219 & 6,40 & 503 & 3219 & & 3219 \\
\hline
\end{tabular}

Source: Department of environment cleanliness and landscaping of Kediri city

\section{Information:}

Number of Needs based on ideal workload

Morning Evening $=$ Area of Islamic Boarding School divided by Workload Coefficient $=28384,41 \mathrm{~m}^{2} / 3219 \mathrm{~m}^{2}=9$

So Ideal Personnel Needs $=9 \times 2 \quad 18$ People

Number of Previous Road Sweep Personnel 17 People -

Shortage of Personnel 1 People

The serviceability of road sweeping officers in Kediri City is still limited. The ability of garbage handling services to date by road sweeping officers is still not optimal, this is proven by the lack of road sweeping officers in Kediri City. According to (Hanyani et al., 2014) the lack of the number of field workers (garbage collectors at TPS and road sweepers with the area to be handled has an impact on increasing the workload of some workers, delays in waste transportation services, and high public complaints.

Waste management in the City of Kediri has not been effective and efficient, this is because there have not been found standard operating procedures (SOP) for waste management in the City of Kediri. The SOP for waste management is a policy instrument as the basis for the monitoring evaluation system. According to (Wilson and Velis;2015) For waste management to be directed and efficient, a waste management policy is formed, which provides certain guidelines for system development.
Table 3.

Job shift schedule in 2018

\begin{tabular}{ccccccc}
\hline NO & SHIFT & $\begin{array}{c}\text { Start } \\
\text { WIB }\end{array}$ & $\begin{array}{c}\text { Finish } \\
\text { WIB }\end{array}$ & $\begin{array}{c}\text { Duration } \\
\text { HOUR }\end{array}$ & $\begin{array}{c}\text { Working } \\
\text { Days } \\
\text { DAY }\end{array}$ & $\begin{array}{c}\text { Total } \\
\text { Work } \\
\text { HOUR }\end{array}$ \\
\hline 1 & $\begin{array}{c}\text { I } \\
\text { ( Morning) }\end{array}$ & 05.00 & $\begin{array}{c}09.0 \\
0\end{array}$ & 4 & 7 & 28 \\
\hline 2 & $\begin{array}{c}\text { II } \\
\text { ( Noon })\end{array}$ & 14.00 & $\begin{array}{c}18.0 \\
0\end{array}$ & 4 & 7 & 28 \\
\hline
\end{tabular}

The schedule only applies to road cleaners and the foreman/cleaning supervisor applies NON-SHIFT.

\section{Conclusion}

The performance of local government policies in the Sanitation and Gardening Office of Kediri City in improving the service quality of street sweeping officers are still not maximal or road sweeping technical workers are still not productive. This is due to the lack of public awareness in waste management, limited waste management facilities, and infrastructure, the lack of performance indicators for field staff services, not supported by standard operating procedures (SOP) for the service performance of street sweeping officers, there is still a lack of operational personnel on street sweeping officers. and there are still some tools that need to be added to support the performance of street sweeping officers. It is known that the service performance of street sweeping officers is maximally supported by the Standard Operating Procedure (SOP) for waste management in the service performance of street sweeping officers who can run effectively and efficiently. Local government policies in improving the service performance of road sweepers in Kediri City so that the performance of road sweepers is more leverage, the Kediri City Government also sets standard operating procedures (SOP) for road sweeping officers, so that there is a standard operating procedure (SOP) for sweeping service performance. way more effective and efficient

\section{REFERENCES}

[1] Basriyanta. 2011. Memanensampah. Jakarta. Yogyakarta :YayasanMitraNetra-Kanisius.

[2] Handayani, F., Djumiati, T., Rihandoyo. 2014. Analisis Efektivitas Bidang Kebersihan Dinas Cipta Karya dan Tata Ruang Kota dalam Pengelolaan Sampah di Kota Salatiga. Journal Of Public Policy And Management Review. Volume 3, Nomor 4. https://ejournal3.undip.ac.id/index.php/jppmr/article/view/6617/638 7.

[3] Lapko, A.; H acia, E.; Wieczorek, R. Collection of Waste from Passenger Ships and Its Impact on the Functioning of Tourist Port City Swinouj'scie. Sustainability-MDPI, 13, 2133. https://doi.org/10.3390/ su13042133.

[4] Lubna Salsabila, E Priyo Purnomo, Hazel D. Jovita. 2021. The Importance of Public Participation in Sustainable Solid Waste Management. Journal of Governance and Public Policy, ISSN: 2460-0164 (print), 2549-7669 (Online) Vol 8, No 2 (2021) : Page no: $106-123$

[5] Muthmainnah.,Adris. 2020. Pengelolaan Sampah Di TempatPembuanganAkhir (TPA) Patommo Sidrap (Tinjauan Yuridis Peraturan Daerah No. 7 Tahun 2016 Tentang Pengelolaan Persampahan), Madani Legal Review. Vol. 4 No. 1. file://C:/Users/G405/Downloads/543-Article\%20Text-1923-1-1020200704.pdf. 
[6] Muttaqien, A.R., Sugiyantoro. 2014. Indentifikasi pengelolaan sampah kota Bandung (studi kasus Komplek Berung Indah, Komplek Perumahan Cibangkong, RW 8 Kelurahan Ciroyom, RW 02 Kelurahan Sukabungah, RW 02 Kelurahan Bina Harapan Cisaranten, dan Kelurahan Maleer). Jurnal Perencanaan Wilayah dan Kota. 2014; 1 (2): 354-62.

[7] Peraturan Daerah Kota Kediri No. 3 Tahun 2015 Tentang Pengelolaan Sampah Kota Kediri.

[8] Pongracz, E., Phillips, P. S., Keiski, R. L. 2014. Evolving the Theory of Waste Management: Defining Key Concepts. Waste Management and the Environment II, p.p. 471-480. http://www.witpress.com/Secure/elibrary/papers/WM04/WM04046F U.pdf (2021-06-10).

[9] Sarbidi. 2009. Kajian Regionalisasi Tempat Pemrosesan Akhir (TPA) Sampah Menggunakan Analisis SWOT (Studi Kasus TPA Benowo Surabaya). Jurnal Pemukiman. Volume 4, No. 1.

[10] Skorupskaitė, K., Junevičius, A. 2017. Waste Management Policy Development in Lithuania Applying Circular Economy Model Public Policy and Administration. Vol. 16, No 1, p. 91-107. https://doi.org/10.5755/j01.ppaa.16.1.18016.

[11] Sucipto, C.D.S. 2012. TeknologiPengolahanDaurUlangSampah, Yogyakarta: Gosyen publishing.

[12] Sudradjat, H.R. 2007. Mengelola sampah kota. Jakarta :Penebar Swadaya Press.

[13] Undang-Undang No. 18 Tahun 2008 Tentang Pengelolaan Sampah.

[14] Wilson, D., Velis, C. 2015. Waste Management - Still a Global Challenge in the 21st Century: An Evidence-based Call for Action. Waste Management \& Research. Vol. 33, No. 12, p.p. 1049-1051.

[15] Zainul, L.M., Farisi, M.L., Azmal, M., Hapressimon.,Nurhidayat, W.O. 2019. Identifikasi dan penilaian Resiko Petugas Penyapu Jalan Raya Kota Balikpapan. Jurnal Keselamatan, Kesehatan Kerjadan Lindungan Lingkungan. Volume 5. No 1. http://jurnal.d4k3.unibabpn.ac.id/ 